\title{
Municipal Solid Waste Characterisation and Quantification as a measure towards Effective Waste Management in the Takoradi Sub-Metro, Ghana*
}

\author{
${ }^{1}$ V. I. Seshie, ${ }^{2}$ K. Obiri-Danso and ${ }^{2}$ K. Miezah \\ ${ }^{1}$ University of Mines and Technology, P. O. Box 237, Tarkwa, Ghana \\ ${ }^{2}$ Kwame Nkrumah University of Science and Technology, Kumasi, Ghana
}

Seshie, V. I., Obiri-Danso, K. and Miezah, K. (2020), "Municipal Solid Waste Characterization and Quantification as a Measure towards Effective Waste Management in the Takoradi Sub-Metro", Ghana Mining Journal, Vol. 20, No. 2, pp. 86-98.

\begin{abstract}
Waste management is a major challenge for many metropolitan and municipal assemblies in Ghana. The quantity of waste generated from the cities keeps increasing at a faster rate without increasing facilities to match its management. In the Takoradi sub-metro for instance, all the waste generated ends up at the final disposal sites without any recovery of the valuables. Proper management of the generated waste requires reliable and informative data which could assist in the collection as well as value addition process. Waste separation efficiency; willingness to separate waste at source; physical composition and per capita waste generated by households within the Takoradi sub-metropolis were studied over a five-week period. Questionnaire, interviews and survey were employed in the collection of the required data. The data were analysed using SPSS. The results showed solid waste composition of $60.0 \%$ organics, $11.5 \%$ plastics, $8.0 \%$ inert materials, $7.1 \%$ papers and cardboard, $5.0 \%$ miscellaneous materials, $2.9 \%$ textiles, $2.4 \%$ metals, $1.5 \%$ glasses and $1.2 \%$ leather and rubber. Over $80 \%$ of the waste fraction has the potential for recovery into other products; with this, $22.7 \%$ could be recycled and $63.6 \%$ suitable for biological conversions such as composting and anaerobic digestion since they have a moisture content as high as 55\%. The average per capita waste generated within the sub-metro was $0.70 \mathrm{~kg} / \mathrm{cap} /$ day. Households were able to separate the organic fractions from the rest of the waste fractions reaching effectiveness of $92 \%$ for organic separation and $83 \%$ for all other wastes. The data generated on the quantity and composition of the waste stream in the Metropolis would play a positive role in solid waste management and help solid waste managers make informed decisions on waste management options.
\end{abstract}

Keywords: Waste Sorting and Separation, Biodegradables, Household Waste, Separation Efficiency

\section{Introduction}

Rapidly increasing populations, economic growth and affluence have contributed positively to generation rate of Municipal Solid Waste (MSW) causing a major challenge to its management worldwide (Aguilar-Virgen et al., 2010; Al-khatib et al., 2010; Fakare et al., 2012; Nabegu, 2010). This particular situation highly manifests in urban cities of developing countries like Ghana, where municipal solid waste management (MSWM) is almost neglected. A walk through the streets of the urban areas of Ghana one finds clear lapses in the waste management situation of the country. According to Freduah (2004), there has been a phenomenal daily increase in the volume of wastes generated in Ghana of recent years resulting in about $83 \%$ of the population dumping their refuse in either authorized or unauthorized sites in their neighbourhood creating unsanitary conditions. In a similar study, Fakare et al. (2012) showed that the problem of waste generation, handling and disposal have reached a disturbing level and a glaring challenge in urban centres of Nigeria. From the same study Fakare et al. (2012) observed that the rate of change of the quantity and composition of domestic waste is quite outstanding and worth frequent investigation.
The social nuisance, healthcare implications and environmental threats pose by improper waste disposal call for efficient waste management strategies since human settlement and waste generation are indispensable. MSW is highly heterogeneous consisting of valuable materials which are often lost because they are not separated from the waste stream. These valuable materials in the waste stream can be recycled and reused, thereby minimising the amount that ends up at the final disposal sites. However, due to the contamination form in which they appear, it is very difficult (if not impossible) to make projections for these valuables regarding recycling, recovery and reuse (Kui, 2007; Walling et al., 2004). This view expressed by Kui (2007) and Walling et al. (2004), is relevant to this research because the waste produced by the people of Takoradi Sub-Metro (TSM) is mixed since there is no form of source separation in the sub-metro. AlKhatib et al. (2010) noted that the composition of solid waste affects the density of the waste, the proposed methodology of disposal and help determine which materials can be reused, reduced at source and recycled. Subsequently, Nabegu (2010) observed that knowledge of waste composition is crucial for selection of the most appropriate technology for the treatment, taking essential precautions on health-related issues and space needed for treatment. Oumarou et al., (2012) therefore believes a comprehensive characterization 
of MSW is crucial to the long term efficient and economical planning for solid waste management.

Efficient waste management relies on adequate statistics on the waste to inform decision making. This therefore, is not the case of waste management approaches employed in many urban settlements of Ghana. Despite the acknowledged relevance of waste management data, there has been inadequate information on the characteristics of municipal solid waste generated in the TSM even though a lot of work has been done in other bigger cities such as Accra, Kumasi and Tamale. This study is purposed to fill this gap by providing data on the generation rate and composition of MSW generated from three different socioeconomic income areas of the TSM to help the city authorities plan properly for managing the waste.

\section{Resources and Methods Used}

Sorting and separation were conducted at the household level of the three socioeconomic income areas (first, second and third class income areas) of the Takoradi sub-metro between January and February 2014.

\subsection{Study Area}

The study was performed in the Takoradi Sub-metro (TSM) which is under the Sekondi-Takoradi Metropolitan Assembly (STMA) of the Western Region of Ghana. The STMA has undergone several changes in status and name. It started as Sekondi Town Council in 1903, under the Town Council Ordinance No 26. Takoradi then joined the administration in 1946 to form a twin community. Sekondi-Takoradi was elevated to the status of a city in 1962. The Assembly was named as Shama Ahanta East Metropolitan Assembly (SAEMA) through a legislative instrument (LI), LI 13116. The assembly was renamed STMA in 2008 through an LI 1928 after Shama was carved out. The STMA is divided into four zones or sub-metropolitan councils namely: Sekondi sub-metro, Effia Kwesimintim Sub-metro, Essikado Ketan Sub-metro and the Takoradi sub-metro (Fig.1).

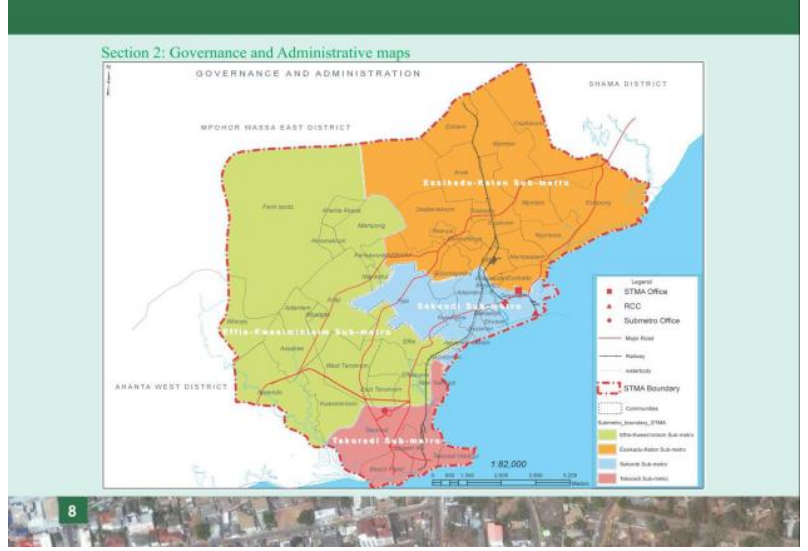

Fig. 1 A map showing the four sub-metros under STMA

Source: Ghana Statistical Service, (Anon, 2012c)

TSM is believed to be the leading economic, commercial and industrial nerve centre of STMA due to the oil find. Oil has been drilled in Ghana in a small way since the late nineteenth century, but Ghana joined the league of oil-producing countries with the discovery of oil in commercial quantities at West of Cape Three Point in the Western Region in June, 2007. Ghana's new oil and gas industry's positive impact is already being felt across the nation and employment is booming across the nation with the STMA housing headquarters of these oil industries (Anon, 2011). Findings indicate that Sekondi-Takoradi is evolving as a location for oil industry cluster. Intense linkages between firms in the core oil industry and other supporting businesses show characteristics of an industrial cluster (Quayson, 2012). The Takoradi harbour for example which is the closest port to the Jubilee field, has thousands of new jobs being created and flooding of new workers has brought an instant turnaround in the fortunes of this city that was in a state of decline. TSM is now the hub of new industrial development in the region (Anon, 2011). The Western Region in general, has experienced a huge migration of people in the last decade but more people have been attracted into the STMA probably with the hope of finding work in the oil-related industries (Planitz and Kuzu, 2014).

According to the 2010 population and housing census, the population of TSM is approximately 97,352 people with gender distribution as 48,470 males and 48,882 females. About 27,920 of the population are between the ages of $0-14 ; 65,292$ between ages 15-62 and 4,140 of the population are above 65 years (Anon, 2012a). The local economy of the Metropolis and the socioeconomic activities of the STMA in general is classified into three major sectors; manufacturing, agriculture and the services. The manufacturing sector is made up of paper manufacturing, timber manufacturing, metal fabrication, micro-enterprises and agro processing 
industries. Twenty-one (21) percent of the population are engaged in agriculture and are into crop farming with $6 \%$ of this population also into fishing. The service sector is made up of shipping/forwarding, hotel/hostel/restaurant (the hospitalities), bulk oil storage and distribution, transport services, harbour and port services as well as commerce (Anon, 2012a). The service sector is the largest employer of the labour force in the Metropolis. It employs about $59.9 \%$ of the labour force who are mostly employed in white-colour jobs in private and public institutions (Anon, 2012a).

\subsection{Classification into Socioeconomic Income Areas by the STMA}

Settlement classification into three basic socioeconomic income areas (first, second and third class residential areas) was developed by the STMA. The STMA classification which is based on socioeconomic development takes into consideration the type of buildings, road network and other social amenities in the area (Anon, 2012b).

\subsubsection{First class income areas}

These areas mostly have single detached houses outside the city centre with gardens/lawns. The first class income areas are usually quiet neighbourhoods having various amenities and access to social services. Not only are those areas quiet, but are also very close to the commercial business district (CBD), making vehicular and pedestrian accessibility to the CBD very easy. Crime rate in such areas is very low due to better security services and the presence of police patrols. Not surprising, the inhabitants are mostly politicians, top public service officials, the rich and the elite in society.

\subsubsection{Second class income areas}

These settlements are characterized by high rise buildings or multiple occupancy properties with no gardens/lawns and close to the central business district. The second class residential areas are characterized by mixed residential properties like semi-detached, flats, and multi-family properties usually referred to in Ghana as the "traditional compound houses". Such compound houses are typically two-storey with 10 to 15 bedrooms. In such areas, basic amenities like schools, hospitals are available and accessible.

\subsubsection{Third Class Income Areas}

The settlements are often characterized by buildings made up of wooden or made shift structures. The communities are unplanned and have many squatters. Low income families dominate these areas which have high crime rate, dense population with noisy environment. These areas normally lack better services and social amenities.

\subsection{Data Types and Sources}

Data used for the research were from both primary and secondary sources. Primary sources of data were obtained through Field survey, face-to-face interviews and questionnaire administration. Field observation involved visit to the selected households to inform occupants about the survey and seek their participation in the survey. Direct interviews were conducted to obtain information from some stakeholders in the waste management sector involving the administrative heads from the Waste Management Departments of the STMA and TSM, the Assemblymen in the selected study areas as well as some officials of the Western Regional Branch of Zoomlion Ghana Limited (a waste management company) including the Regional Manager, his Assistant and some field supervisors.

A well-structured questionnaire was developed and administered randomly to sample households for collection of relevant data. This was followed by field measurements of waste samples collected from households.

Books, articles, newspapers, journals and information from the internet were some of the sources where secondary data used were obtained.

\subsection{Sample Size Determination and Sampling of Households}

The needed sample size required to obtain the right and representative information were determined using the formula of sampling for continuous variable measurements reported by Cochran (1977) which was applied by Puopiel (2010) and Gomez et al. (2008) as in Equation below.

$$
\left.\mathrm{n}=\mathrm{Z}^{2}\left[\mathrm{P}^{2}\right) /\left(\mathrm{D}^{2}\right)\right]
$$

where $\mathrm{n}=$ the sample size, $\mathrm{Z}=$ value for a selected alpha level of each tail $=1.96$ (the alpha level of 0.05 indicates the level of risk the researcher is willing to take that true margin of error may exceed the acceptable margin of error), $\mathrm{P}=$ estimate of standard deviation in the population and $\mathrm{D}=$ acceptable margin of error for mean being estimated.

Also, following the approach used Nordtest (1995) for study which involves stratification into socioeconomic income areas, 25-40 households were selected randomly (Table 1). 
Table 1 Number of Households Selected from the Socioeconomic Areas as Well as the Sample Size Collected for the Analysis

\begin{tabular}{|l|l|l|l|l|}
\hline Sn & $\begin{array}{c}\text { Class of } \\
\text { Resident } \\
\text { ial Area }\end{array}$ & $\begin{array}{c}\text { Residential } \\
\text { Area }\end{array}$ & $\begin{array}{c}\text { Number of } \\
\text { Household } \\
\text { s }\end{array}$ & $\begin{array}{c}\text { Number } \\
\text { of } \\
\text { Samples }\end{array}$ \\
\hline 1 & First & Beach road & 28 & 420 \\
\hline 2 & Second & $\begin{array}{l}\text { Essikafoam } \\
\text { batem no. 1 }\end{array}$ & 34 & 510 \\
\hline 3 & Third & Adakope & 31 & 465 \\
\hline
\end{tabular}

After the determination of sample size required and number of households needed, sampling of the households was carried out randomly within the stratified socioeconomic areas. Households were sampled by selecting every Kth house starting from the direction of the first point of contact with any house in the selected area.

\subsection{Sorting of Generated Waste}

The randomly selected households were educated on how to sort and separate their waste for a period of two days. During the period, a one-way separation method involving separation of waste into two categories Biodegradables (organics excluding papers) and All other wastes was explained to them. Also, the importance of the survey was explained to the respondents to encourage their full participation. Feedback was collected from households to test their understanding of the sorting and separation activities. The feedback was both verbal and filling the questionnaire to state whether or not respondents understood how separation into the various categories is to be carried out.

Households were made to separate their waste into two designated waste bins or polythene bags supplied to areas which had no bins. Each bin or polythene bag was labelled either 'Biodegradable wastes except Paper' or 'All Other Wastes'. The separated wastes from each household were collected three (3) times in a week (Mondays, Wednesday and Fridays) over a period of five (5) weeks. Each collected waste further sorted and separated into different fractions for determination of the composition.

\subsection{Waste Quantification}

The per capita generation of the waste and the total waste generation was deduced from the waste components separated by weighing. This was done for the mixed wastes and also the separated fractions using the formula below:

Per capita waste generation $=\frac{\text { weight of MSW generated at the household }}{\text { Total number of persons in the household } \times \text { total generation days }}$

\subsection{Physical Composition of MSW Analysis}

MSW from the households was segregated into the following compositions and analysed by weight as well as the percentage composition described by the Anon. (2008) method for separation of unprocessed waste (Table 2).

Table 2 Fractions of MSW and their sub-fraction into which the further sorting was done

\begin{tabular}{|c|c|}
\hline $\begin{array}{l}\text { Major } \\
\text { Fraction }\end{array}$ & Sub-fractions \\
\hline $\begin{array}{l}\text { Organic } \\
\text { waste }\end{array}$ & $\begin{array}{l}\text { Food waste, yard waste and } \\
\text { wood }\end{array}$ \\
\hline Plastics & $\begin{array}{l}\text { PET, HDPE, PVC, LDPE, } \\
\text { PP, PS and Pure water } \\
\text { sachet }\end{array}$ \\
\hline Metal & Ferrous and Non-ferrous \\
\hline Papers & $\begin{array}{l}\text { packaging/cardboard/office } \\
\text { print/sheet/newsprint and } \\
\text { tissue/diaper }\end{array}$ \\
\hline $\begin{array}{l}\text { Leather and } \\
\text { Rubber }\end{array}$ & \\
\hline Textiles & Cloths and rags \\
\hline Glass & Plates, cups, bottles etc \\
\hline Inerts & Sand, rocks, ash, etc \\
\hline Miscellaneous & $\begin{array}{l}\text { all other fraction not in the } \\
\text { above categories }\end{array}$ \\
\hline
\end{tabular}

The composition of the various fractions of the wastes was determined using the equation below

$$
\% \text { Composition of separated waste }=\frac{\text { Weight of separated waste }}{\text { The total mixed weight of sample }} \times 100
$$

\subsection{Separation Efficiency}

The efficiency of the separation was assessed by weighing the sorted waste in the designated bin or polythene bag provided as a percentage over the total weight of waste in the same bin.

Separation efficiency $=\frac{\text { weight of target waste separated into the right bin } / \text { polythene bag }}{\text { total weight of all waste separated into the same bin/polythene bag }} \times 100$

The administered questionnaire helped to determine the preparedness of the participants to separate their waste at any given period. This was compared with how best the separation was done.

\subsection{Determination of Moisture Content}

Following the method described by Bryant et al. (2010), the moisture content of the biodegradables 
or organic waste (food waste and yard trimmings) was determined by heating the waste in an oven to a temperature of $105^{\circ} \mathrm{C}$ for $12 \mathrm{~h}$ until the weight stabilized. The difference between the weight before oven drying and after oven drying gave the moisture content of the waste (equation 4). The moisture content of the biodegradable wastes from the various socioeconomic income areas was determined.

The moisture content as a percentage was determined from the formula below:

$$
\text { Moisture content }(\%)=\frac{(a-b)}{a} \times 100
$$

where $\mathrm{a}=$ initial weight of the sample as delivered $\mathrm{b}=$ weight of the sample after drying at $105^{\circ}$ C.

\subsection{Data Analysis}

The Statistical Package for Social Sciences (SPSS) 16 for Windows and Microsoft Excel were used to analyse the data obtained. SPSS was used to analyze the correlation between income levels of the three socioeconomic classes and the per capita generation and also income levels against household size. Oneway ANOVA was used to test for significant difference in waste generation rate between the three classes. The mean value in relation to the standard error of the separation effectiveness of the waste in the three classes was determined using the SPSS. The significance was at $\mathrm{p}=0.05(95 \%$ confidence level).

\section{Results and Discussion}

\subsection{Physical Composition of Waste}

The percentage composition by weight of the fractions of waste from households in the three socioeconomic income areas analysed over the entire period of the survey is shown in Table 4. A total waste amount of $11,708.4 \mathrm{~kg}$ was analysed, out of which $3,757.5 \mathrm{~kg}$ was collected from the third class socioeconomic income area; $3,712.9 \mathrm{~kg}$ from the second class income area and $4238.0 \mathrm{~kg}$ also from the first class income area (Table 4). The results show the average solid waste composition of $60.0 \%$ biodegradables; $11.5 \%$ plastics, $8.0 \%$ inert materials, $7.1 \%$ paper and cardboard, 5.0\% miscellaneous materials, $2.9 \%$ textiles, $2.4 \%$ metals, $1.5 \%$ glass and $1.2 \%$ leather and rubber from the three socioeconomic income areas. The percentage composition of biodegradable waste was highest for all the three socioeconomic income areas while leather and rubber were least fractions of wastes from Beach road. Glass also was the least fraction from both Essikafoambatem No. 1 and Adakope.

Food waste formed the highest fraction $(58.6 \%$ of the waste stream on average) of the biodegradable waste from all the three socioeconomic income class areas. This is also the case in many developing countries where cooking of unprocessed foodstuff generates a significant amount of putrescible wastes. In contrast, developed countries depend a lot on processed and ready-to-eat foods leading to a lower percentage generation of organic foods, but a higher percentage of packaging materials. Al-khatib et al. (2010), and Gomez et al. (2009), reported of garden and food waste as contributing to $65.1 \%$ of the total waste stream in most developing countries (Table $3)$.

Table 3 Composition of MSW components (weight basis)

\begin{tabular}{|c|c|c|c|c|c|c|c|c|c|c|c|c|}
\hline \multirow[t]{3}{*}{ Waste } & \multicolumn{9}{|c|}{$\begin{array}{l}\text { Sampling } \\
\text { location }\end{array}$} & \multirow{2}{*}{\multicolumn{3}{|c|}{$\begin{array}{l}\text { Overall composition in the } \\
\text { district }\end{array}$}} \\
\hline & \multicolumn{3}{|c|}{$\begin{array}{l}\text { Beit Imrin (western } \\
\text { locality) }\end{array}$} & \multicolumn{3}{|c|}{ Beita (eastern locality) } & \multicolumn{2}{|l|}{$\begin{array}{l}\text { Nablus } \\
\text { city }\end{array}$} & & & & \\
\hline & av $(\mathrm{kg})$ & s.d. & $\%$ & $\begin{array}{r}\text { av } \\
(\mathrm{kg})\end{array}$ & s.d. & $\%$ & av $(\mathrm{kg})$ & s.d. & $\%$ & av $(\mathrm{kg})$ & s.d. & $\%$ \\
\hline Plastic & 6.7 & 2.4 & 5.2 & 9.9 & 3.4 & 8.6 & 11.0 & 4.9 & 9.4 & 9.2 & 2.2 & 7.6 \\
\hline Metal & 2.5 & 1.7 & 2.0 & 3.7 & 2.5 & 3.2 & 4.1 & 2.0 & 3.5 & 3.4 & 0.8 & 2.8 \\
\hline Glass & 3.8 & 2.3 & 2.9 & 3.4 & 1.4 & 3.0 & 3.4 & 2.3 & 2.9 & 3.6 & 0.2 & 2.9 \\
\hline Paper \& Card & 6.4 & 1.9 & 4.9 & 12.4 & 2.6 & 10.8 & 14.3 & 6.9 & 12.2 & 11.0 & 4.2 & 9.1 \\
\hline Organic & 95.3 & 7.9 & 73.4 & 72.1 & 11.7 & 62.6 & 68.3 & 18.6 & 58.3 & 78.6 & 14.6 & 65.1 \\
\hline Textile & 3.9 & 2.6 & 3.0 & 3.1 & 2.0 & 2.7 & 4.2 & 2.7 & 3.6 & 3.7 & 0.6 & 3.1 \\
\hline Other & 5.8 & 3.5 & 4.5 & 6.6 & 3.2 & 5.7 & 7.2 & 3.7 & 6.1 & 6.5 & 0.7 & 5.4 \\
\hline$<10 \mathrm{~mm}$ & 5.4 & 3.4 & 4.1 & 4.1 & 3.2 & 3.5 & 4.6 & 2.9 & 3.9 & 4.7 & 0.7 & 3.9 \\
\hline $\begin{array}{l}\text { Overall density } \\
\left(\mathrm{kg} / \mathrm{m}^{3}\right)\end{array}$ & 295 & & & 230 & & & 234 & & & 240 & & \\
\hline
\end{tabular}


The percentage of putrescible reported in this study $(60.0 \%)$ is similar to this reported fractions of biodegradable wastes. The percentages of biodegradable waste in municipal solid waste in selected African cities were $56 \%$ in Ibadan, $75 \%$ in Kampala, $85 \%$ in Accra, $94 \%$ in Kigali and $51 \%$ in Nairobi (Oyelola and Babatunde, 2008).

Food waste as a fraction of the biodegradables, was highest in the second class income area and this may be due to the large numbers of local restaurants "Chop bars" located in homes in that community where some leftovers from these Chop bars find their way into household bins. The third class area had the least fraction of food waste since most of these food wastes were used as feed for animal. Yard trimmings formed the bulk of the waste in the first class income areas where residents had lawns and gardens on their compounds.

The next highest fraction of waste aside the biodegradable waste was plastic waste mainly composed of LDPE and pure water sachets (HDPE). Generation of plastics was highest in the second class income area $(14.3 \%)$ and lowest $(10.0 \%)$ in the first class income area. Paper waste was significantly made up of cardboards, magazines, disposal tissues and diapers in all the three socioeconomic areas. Comparatively, paper waste fraction was lower in the study areas of the Takoradi Sub-metro than it is in developed cities/countries. Most paper wastes generated in households of the Sub-metro (e.g. newspapers, magazines) are waste sold by offices and institutions to food vendors who use them in wrapping food items. The first class income area generated more packaging waste in total (paper, metals, plastics and glass) than the second class income area, and the third class income area generated the least of this type of waste. The highest percentage of packaging waste generated by the high income population indicated its greater purchasing power, reflected in its consumption ability. Oyelola and Babatunde (2008), reported that the packaging fractions of household waste have a direct relationship with household income; the wealthier households produce significantly higher percentages of paper, plastic, metal and glass wastes use in packaging items. The composition of packaging materials from the first class income areas in this study confirmed this. The least production of packaging waste was from the third class income area.

Textiles waste was highest in the second class income area $(4.9 \%)$ compared to the $1.9 \%$ and $1.8 \%$ from the third and first class income areas, respectively. The least fraction of textile waste from the first class income area could be due to the fact that these settlements often donate used clothing to the less privilege in society and also offer to their maidservants or hired workers as gift. Even though Textile waste from the first class income areas happened to be least, $1.8 \%$, this value is comparable to that for the third class income areas, $1.9 \%$. The value recorded for the third class income area is attributed to the fact that the people hardly discard their old cloths but transfer them to other members of the family due to their financial status.

Over $5.1 \%$ disposable tissues and diapers were generated in the first class socioeconomic area followed by the second class socioeconomic area $(3.8 \%)$ and the third class income areas, $2.5 \%$. The third class income areas generated the highest $(21.8 \%)$ amount of inert (sand and dirt) waste and also highest miscellaneous items (12.0\%). This may be due to the patronage of second-hand electronic items and disposable batteries compared to only $1.2 \%$ in the first class socioeconomic areas (Table 4).

From the study, biodegradable waste constituted $65.0 \%$ and non-biodegradable waste $34.3 \%$. It can be seen that biodegradable waste generated by the three socioeconomic areas decreased steadily and the non-biodegradable waste increased steadily from the first to the third class (Fig.2). However, there was no significant different in the fractions of these biodegradables and non-biodegradables across the three socioeconomic areas at $\mathrm{P}<0.05(\mathrm{P}=0.96)$.

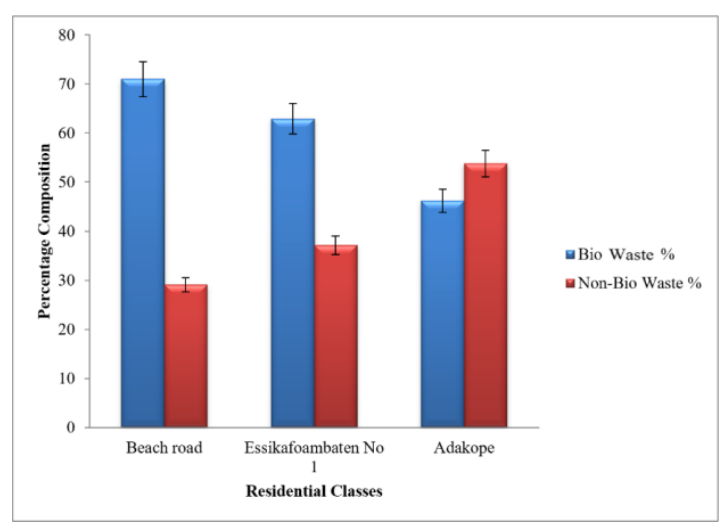

Fig. 2 Categorisation of Waste stream into Biodegradables and Non-Biodegradables 
Table 4 Total Waste Amounts Analysed and the Physical Composition of MSW from the Three Socioeconomic Income Areas

\begin{tabular}{|c|c|c|c|c|c|c|c|}
\hline \multirow{3}{*}{$\begin{array}{c}\begin{array}{c}\text { Physical Composition } \\
\text { of Waste }\end{array} \\
\text { Biodegradables }\end{array}$} & \multicolumn{6}{|c|}{ Class Residential Settlements } & \multirow{3}{*}{ P-value } \\
\hline & \multicolumn{2}{|c|}{ Beach Road } & \multicolumn{2}{|c|}{ Essikafoambantem no 1} & \multicolumn{2}{|c|}{ Adakope } & \\
\hline & Wt kg & Wt \% & Wt kg & Wt \% & Wt kg & Wt \% & \\
\hline Food Waste & 1799.77 & 42.47 & 2255.93 & 60.76 & 1376 & 36.62 & \\
\hline Yard Waste & 1109.29 & 26.18 & 44.3 & 1.19 & 317.5 & 8.45 & \\
\hline \multirow[t]{2}{*}{ Wood } & 97.8 & 2.31 & 34.9 & 0.94 & 42.1 & 1.12 & \\
\hline & 3006.86 & $70.95^{a}$ & 2335.13 & $62.89^{a}$ & 1736 & $46.19^{b}$ & 0.96 \\
\hline \multicolumn{8}{|l|}{ Non-Biodegradable } \\
\hline News/Office Print/Cardboard & 152.7 & 3.6 & 167.56 & 4.52 & 93.8 & 2.49 & \\
\hline \multirow[t]{2}{*}{ Tissue Paper/Diaper } & 217.9 & 5.14 & 141.3 & 3.81 & 93.5 & 2.49 & \\
\hline & 370.6 & $8.74^{d}$ & 308.86 & $8.32^{d}$ & 187.3 & $4.98^{e}$ & 0.66 \\
\hline Plastic Film/LDPE & 146.4 & 3.45 & 249.02 & 6.71 & 219.6 & 5.84 & \\
\hline PET & 85.7 & 2.02 & 50.91 & 1.37 & 29.9 & 0.8 & \\
\hline HDPE & 45.5 & 1.07 & 36.2 & 0.97 & 24.5 & 0.65 & \\
\hline Pure water sachet (HDPE) & 54.65 & 1.29 & 125.31 & 3.38 & 65.5 & 1.74 & \\
\hline $\mathbf{P P}$ & 33.5 & 0.79 & 28.51 & 0.77 & 17.7 & 0.47 & \\
\hline PS & 32.95 & 0.78 & 15.32 & 0.41 & 4.2 & 0.11 & \\
\hline PVC & 11.1 & 0.26 & 6.7 & 0.18 & 8.8 & 0.23 & \\
\hline \multirow[t]{2}{*}{ Other Plastics } & 13.5 & 0.32 & 20.6 & 0.55 & 8.91 & 0.24 & \\
\hline & 423.3 & $9.99^{d}$ & 532.58 & $14.34^{d}$ & 379.1 & $10.09^{d}$ & 0.87 \\
\hline Metals & 132.9 & $3.14^{e}$ & 93.25 & $2.51^{\mathrm{e}}$ & 55.6 & $1.48^{\mathrm{e}}$ & 0.71 \\
\hline Glass & 116.4 & $2.75^{e}$ & 45.7 & $1.23^{\mathrm{e}}$ & 20.6 & $0.55^{\mathrm{f}}$ & 0.15 \\
\hline Leather and Rubber & 27.1 & $0.64^{f}$ & 83 & $2.24^{\mathrm{e}}$ & 29.8 & $0.79^{f}$ & \\
\hline Textiles & 79.8 & $1.88^{e}$ & 181.22 & $4.88^{\mathrm{e}}$ & 73.6 & $1.96^{\mathrm{e}}$ & \\
\hline Inert & 33.2 & $0.78^{f}$ & 55.5 & $1.49^{\mathrm{e}}$ & 820.8 & $21.84^{c}$ & \\
\hline Miscellaneous & 46.7 & $1.1^{f}$ & 68.3 & $1.84^{\mathrm{e}}$ & 450.7 & $11.99^{c}$ & \\
\hline TOTAL & 4237.96 & 100 & 3712.94 & 100 & 3757 & 100 & \\
\hline
\end{tabular}

**Percentages of Waste Composition in Italics

"NB: Values having the same alphabet code significantly the same and differ with others with a different alphabet."

\subsection{Effectiveness of the Separation}

The willingness of households to separate waste at source was $71.4 \%, 79.4 \%$ and $64.5 \%$ on average for first, second and third class income areas, respectively as observed from the administered questionnaire. This was consistent with the outcome of research conducted by Anarfi (2013), which recorded $73.3 \%$ and $86.7 \%$ for low and middle income areas, respectively. It also agreed with results obtained by Oduro-Kwarteng et al., (2016), which had it that over $70 \%$ of respondents in their study area were willing to separate their household waste at source. Respondents from the third class income area had the least response on willingness to separate their waste at source; the explanation most of the households in the area gave was the belief that extra cost was going to be charged.

Source separation of waste needs guaranteed participation of communities and this could be measured by the willingness of people to separate waste at source. This measurement may not be the same as the actual number participating in the separation of the waste at source due to change of mind or the mere fact that neighbours are separating their waste.

The separation efficiency for sorting into the bin designated for organics were $95.7 \%, 90.9 \%$ and $91.3 \%$ for the first, second and third class income areas, respectively while in the same way $79.8 \%$, $84.7 \%$ and $85.9 \%$ were achieved for separating into the bin for all other wastes. 
The trend in separation effectiveness for sorting into the bin for organic or labelled biodegradables from day 1 to the $15^{\text {th }}$ sorting day is shown in Fig. 3 while separation effectiveness for separating into the bin for all other waste is in Fig. 4. There was higher separation effectiveness for organics, above $90 \%$ in almost all the sorting days across the socioeconomic income areas, except on few occasions where the second and third class income areas recorded value below $90 \%$, but above $85 \%$. In the case of sorting waste into the bin for other wastes, the achievement of the third class income area was the highest except on sorting day 11 where the performance came from above $80 \%$ average to about $65 \%$ (Fig. 4). The second class income area had separation effectiveness ranging from $74-93 \%$ while in the first class income area $77-84 \%$ was recorded. There was a slight fluctuation in the effectiveness of the separation as the survey proceeded but constant education kept sustaining the separation across the socioeconomic areas. Some of the reasons which led to lower separation effectiveness in separating into the bin for other waste were the fact that separation of the waste in most first class income areas was done by house maids who had low level of education. Some household's members were most of the times out of the house, hence could not be fully educated on the sorting and separation process.

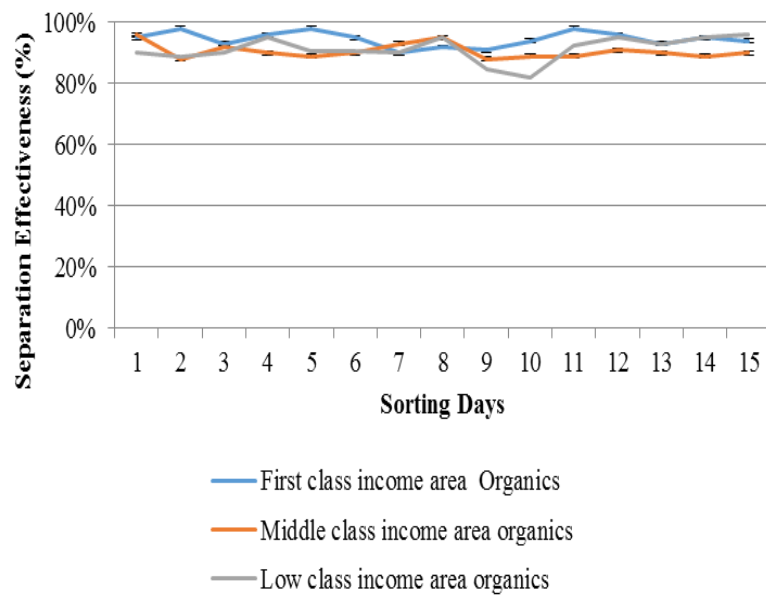

Fig. 3 Effectiveness of separation of waste into the waste bin designated for organic waste by households from the three socioeconomic areas in TSM

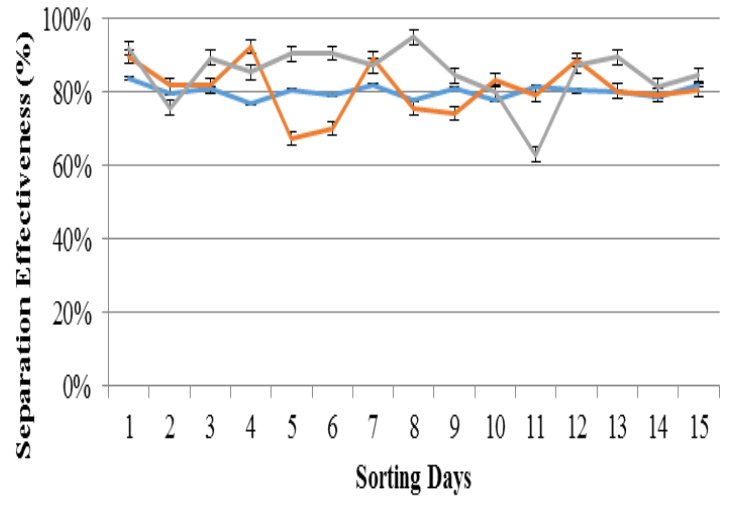

\section{-First class income area other waste \\ - Second class income area other waste \\ - Third class income area other waste}

Fig. 4 Effectiveness of Separation of Waste into the Waste Bin Designated For All Other Waste by Households from the Three Socioeconomic Areas in TSM

The high percentage efficiency in the separation was probably due to the explanation given to them on the benefits of source separation compared to the existing solid waste management system in the submetro. Most people believed if source separation is part of the solution to proper solid waste management in the metropolis and the country, then they were willing to separate.

Analysis of the administered questionnaire indicated that none of the households in the study area does source separation. However, there were a high number of residents $(72.04 \%)$ who were willing to separate their waste. The desire to access other disposal options in the community was high. For instance, $77.4 \%$ of respondents are willing to send waste for recycling whiles $74.2 \%$ of respondents are willing to accept the concept of home composting.

\subsection{Per Capita Waste Generation}

The per capita generation rates of waste generated in the three socioeconomic income areas in the TSM is shown in Table 5. The generation rate was highest in the first class income areas having a rate of 0.76 $\mathrm{kg} / \mathrm{capita} /$ day compared to the second and third class income areas which had a generation rate of 0.66 $\mathrm{kg} / \mathrm{capita} /$ day and $0.69 \mathrm{~kg} / \mathrm{capita} /$ day, respectively. The average generation rate for the three socioeconomic income areas was 0.70 . There was no significant difference in the generation rate of waste per capita among the three socioeconomic income areas at $5 \%$ significance level.

The average waste generation rate from this study, $0.70 \mathrm{~kg} / \mathrm{capita} /$ day is similar to the per capita 
generation of $0.75 \mathrm{~kg} / \mathrm{ca}$ for metropolitan and municipal areas reported by (Anon., 2010). However, this waste generation rate is above the estimated national average of $0.5 \mathrm{~kg} /$ capita/ day found by Mensah and Larbi (2005). The result obtained in this study was in line with global trend of waste generation rate for developing countries (0.5-0.9 kg/capita/day) reported by Gomez et al.
(2009). Developed countries normally produce more solid waste per capita $(0.7-1.8 \mathrm{~kg} /$ capita/day) compared to middle income and low income countries or developing countries (Gomez et al., 2009). In the city of Kitwe, Zambia, the per capita generation in the year 2003 for first, second and third class income areas were $0.40,0.60$ and 0.68 $\mathrm{kg} / \mathrm{cap} /$ day, respectively which were slightly below $0.69,0.66$ and 0.76 for first, second and third class income areas, respectively observed in this study.

Table 5 Per Capita Waste Generation from Households of Three Socio-Economic Areas in Takoradi SubMetro of the Western Region

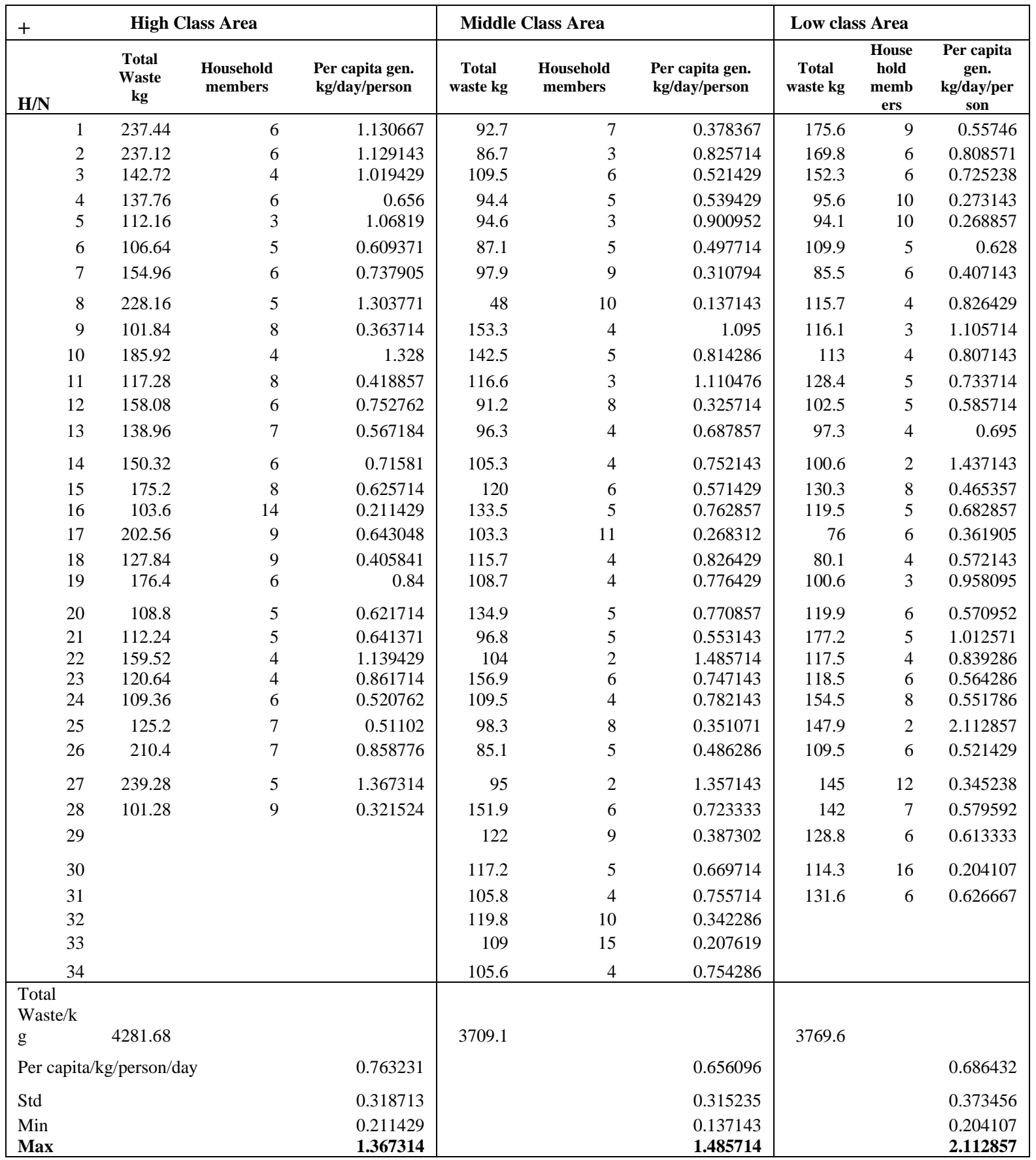




\subsection{Relationship between Per Capita Waste Generation and Income Levels of the Study Area}

The vast difference in the per capita generation of waste between the developed and developing countries confirms a direct correlation between the economic status of a country and household solid waste (HSW) generation rate (Bernache-Perez et al., 2001). In this study, the per capita waste generation weakly correlated with income levels negatively that is as income levels rise the amount of waste generated reduced corresponding to the same observation made by Aisa (2013). This is because most households in the lower income areas purchase cheap inferior items that do not last and have to be discarded in a relatively shorter time; higher income earners buy quality and durable products that last longer. Most of the people living in the first class income areas were Civil servants/ employees in private company or NGOs and students who spent most of their time outside their homes. Furthermore, they did have breakfast and lunch outside their homes due to their busy schedule, contributing to a reduced rate in waste generation at their residence. However, the correlation was weak showing no or negligible relationship existed between the income level and per capita waste generation (Table 6).

Table 6 Correlation between Per Capita Waste Generation and Household Size

\begin{tabular}{|l|c|c|c|}
\hline \multicolumn{4}{|c|}{ Income Level of Various Households } \\
\hline $\begin{array}{l}\text { Average Waste } \\
\text { per capita }\end{array}$ & $\begin{array}{c}\text { First } \\
\text { Class } \\
\text { Income } \\
\text { Area }\end{array}$ & $\begin{array}{c}\text { Second } \\
\text { Class } \\
\text { Income } \\
\text { Area }\end{array}$ & $\begin{array}{c}\text { Third } \\
\text { Class } \\
\text { Income } \\
\text { Area }\end{array}$ \\
\hline $\begin{array}{l}\text { First Class } \\
\text { Income Area }\end{array}$ & -0.0082 & - & - \\
\hline $\begin{array}{l}\text { Second Class } \\
\text { Income Area }\end{array}$ & - & -0.1838 & \\
\hline $\begin{array}{l}\text { Third Class } \\
\text { Income Area }\end{array}$ & - & - & -0.0177 \\
\hline
\end{tabular}

**Correlation is significant at the 0.01 level (2tailed)

\subsection{Relationship between Household Size and Generation Rate of Waste}

There was a strong negative correlation between household size and the per capita waste generation (Table 7). Qdais et al. (1997), Bolaane and Ali, (2004) and Ojeda-Benitez et al. (2008), have shown that as the number of household members increases, waste generation per capita decreases. Thus, the larger the household size, the smaller the per capita waste generation (Fig.5). The reason for this may be attributed to households' social and economic activities bothering on waste generation. Odais et al.
(1997) explained that bigger household members usually cook in bulk and share together or buy packaging items shared by all members compared to households having smaller members who buy similar items packed in the same way.

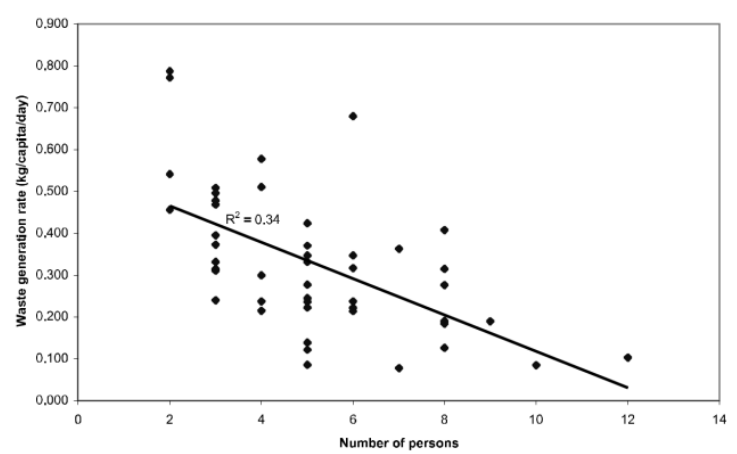

Fig. 5 Relationship between Waste Generation and Household Size

Source: Bolaane and Ali, (2004)

Table 7 Relationship between Per Capita Waste Generation and Household Size

\begin{tabular}{|l|c|c|c|}
\hline \multicolumn{4}{|c|}{ Household Size of the Various Households } \\
\hline $\begin{array}{l}\text { Average } \\
\text { Waste per } \\
\text { capita }\end{array}$ & $\begin{array}{c}\text { First } \\
\text { Class } \\
\text { Income } \\
\text { Area }\end{array}$ & $\begin{array}{c}\text { Second } \\
\text { Class } \\
\text { Income } \\
\text { Area }\end{array}$ & $\begin{array}{c}\text { Third Class } \\
\text { Income } \\
\text { Area }\end{array}$ \\
\hline $\begin{array}{l}\text { First Class } \\
\text { Income } \\
\text { Area }\end{array}$ & -0.711 & - & - \\
\hline $\begin{array}{l}\text { Second } \\
\text { Class } \\
\text { Income } \\
\text { Area }\end{array}$ & - & -0.825 & - \\
\hline $\begin{array}{l}\text { Third Class } \\
\text { Income } \\
\text { Area }\end{array}$ & - & - & -0.706 \\
\hline
\end{tabular}

\subsection{Potential for Recycling}

The percentage fractions of waste from the three socioeconomic areas having potential for recycling and composting are presented in Table 8 . On the average, $81.7 \%$ of the total waste generated in the three socioeconomic areas had potential for recovery into other useful output such as energy recovery; out of this, $22.7 \%$ could be recycled and $77.3 \%$ composted or suitable for other biological conversion. The highest fraction of compostable wastes $(73 \%$ of the total waste stream) were generated from the first class income areas, Beach Road and the least (48\%) from the third class income area, Adakope. Recyclable wastes on the another hand were obtained most $(24 \%)$ from the waste stream generated by the second class income area. The third class income area, Adakope, generated the least fractions of both recyclable and compostable wastes. For the residual waste generated, the third 
class area generated the highest (inert and miscellaneous).

Generally, this trend of high compostable fractions in household wastes can be confirmed in low and middle income countries where a high percentage of compostable organic matter in the urban waste stream had been found ranging from 40 to $85 \%$ (Oyelola and Babatunde 2008) and recommended composting as a suitable treatment option for household wastes with a high percentage of organic matter (50\%-90\%). In Ensenada, Mexico, $86.4 \%$ of the waste generated had the potential to be used for recovery with only $13.7 \%$ ending up at the final disposal site (Aguilar-Virgen et al., 2010) and this compares fairly with the study from the TSM.

ANOVA test on compostable waste generated from the three socioeconomic areas showed no significant difference between the compostable wastes generated in the first and second class income areas. However, there was a significant difference between the first class and third class socioeconomic areas. In the case of recyclable wastes the same amount of waste was significantly generated in the first and second class income areas but varied among these areas and the third class income area. For the residual waste generated the third class area generated the highest.

Table 8 Fraction of Msw from the TSM Suitable for Recycling and Composting

\begin{tabular}{|c|c|c|c|}
\hline ITEM & $\begin{array}{l}\text { Beach } \\
\text { Road \% }\end{array}$ & $\begin{array}{l}\text { Essikafoambatem } \\
\text { N0 } 1 \%\end{array}$ & $\begin{array}{l}\text { Adakope } \\
\%\end{array}$ \\
\hline Compostable & $72^{\mathrm{a}}$ & $67^{\mathrm{a}}$ & $48^{\mathrm{b}}$ \\
\hline Recyclable & $19^{c}$ & $24^{\mathrm{c}}$ & $15^{\mathrm{d}}$ \\
\hline Residue & $9^{e}$ & $9^{\mathrm{e}}$ & $37^{\mathrm{b}}$ \\
\hline
\end{tabular}

NB: Values having the same alphabet code are significantly the same and differ with others with different alphabet

\subsection{Moisture Content of the Various Socioeconomic Classes of Solid Waste}

The moisture content of the organic wastes from all the three income areas of residence ranged from $44.1 \%$ to $61.9 \%$, with waste from Adakope having the lowest moisture content and Essikafoambatem No. 1 the highest (Table 9).

Food and yard waste contributed higher amounts of moisture to the waste stream. Although moisture content is important in bioconversion process, it affects the weight making the collection and transportation processes overwhelming tasks. Often, moisture content in waste increases the weight of waste that gets to the disposal sites and therefore increases the leachates flow rate from the disposal site. From the study, two of the three socioeconomic income areas had ideal moisture contents in their waste; Beach Road, 59.1\% and Essikafoambatem No $1,61.9 \%$ which is in the optimum range for microbial activities. The optimum moisture content often ranges from $50 \%$ to $60 \%$ for most metabolic activity to occur (Lopez Zavala and Funamizu, 2005). Below this range, microbial activity decreases and biological conversion processes are slowed. The moisture contents obtained in this study compared fairly with work conducted by Kazimbaya-Senkwe and Mwale (2001).

Table 9 Moisture Content of MSW

\begin{tabular}{cccc}
\hline $\begin{array}{c}\text { Class/com } \\
\text { ponent }\end{array}$ & $\begin{array}{c}\text { Beach } \\
\text { Road/first } \\
\text { class }\end{array}$ & $\begin{array}{c}\text { Essikafoambatem No } \\
\text { 1/ second class }\end{array}$ & $\begin{array}{c}\text { Adakope/third } \\
\text { class }\end{array}$ \\
\hline $\begin{array}{c}\text { Moisture } \\
\%\end{array}$ & 59.05 & 61.87 & 44.06 \\
\hline
\end{tabular}

\section{Conclusions}

Household wastes from the Takoradi sub-metro were mainly food, yard waste, wood, paper and cardboard, plastics, glass, textiles, leather and rubber and metals just like it is in many cities from developing countries. Organic wastes from all the three socioeconomic groups were about $60 \%$ and plastics $11.74 \%$.

Solid waste fractions from the TSM were averagely made up of $81.7 \%$ recyclables and compostable. Only $18.4 \%$ of the waste may destined for disposal if appropriate recycling, anaerobic digestion and composting facilities are installed for processing. Although waste separation was not practiced in the sub-metropolis there was a general willingness among the inhabitants of the metropolis to separate waste at source. The average per capita waste generation for TSM was $0.70 \mathrm{~kg} / \mathrm{cap} /$ day, for all the three socio-economic incomes levels with the highest waste generation $(0.76 \mathrm{~kg} / \mathrm{cap} /$ day being households from the first class income areas. Moisture content of the waste stream in TSM was $55 \%$ suggesting that biological conversion could be the best treatment option for the waste.

\section{Acknowledgements}

My sincere appreciation goes to my supervisor. A big thank you to Zoomlion Ghana Limited, Takoradi for sponsorship and supporting the field work. I also thank the Assemblymen of Beach Road, Essikafoambatem No 1 and Adakope for their assistance throughout the survey.

\section{References}

Aguilar-Virgen, Q., Armijo-de Vega, C., TaboadaGonzalez, P. A. and Ojeda-Benitez, S. (2010), "Municipal Solid Waste Generation and Characterization in Ensenada, Mexico", Open 
Waste Management Journal, Vol. 3, pp. 140145.

Aisa, S. O. (2013), "characterization of household waste in Kinondoni Municipality, Dar Essalaam", Academic Journal of Interdisplinary Studies, Vol. 2 No. 13, pp. 35-46.

Al-khatib, I. A., Monou, M., Abdul-Salam, F., Abu, Z., Shaheen, H. Q. and Kassinos, D. (2010), "Solid Waste Characterization, Quantification and Management Practises in Developing Countries, A case study: Nablus District Palestine", Journal of Environmental Management, Vol. 9, pp. 1131-1138.

Anarfi, K.P. (2013), "Source Separation, Characterization and Recycling Potential of Household Solid Waste. A case study of Kumasi, Ghana", Unpublished MSc. thesis Report, Kwame Nkrumah University of Science and Technology, Kumasi, Ghana, 121 pp.

Anon. (2008). "Standard Test Method for Determination of the Composition of Unprocessed Municipal Solid Waste", American Society for Testing and Materials International, USA, 6 pp.

Anon (2011), "Ghana: The New Land of Opportunity for Oil and Gas Investment: Overview of the Potential for Ghanaian Oil and Gas Investors" http://maritimehubafrica.com/uploads/news_attachment/Report_Ghana_Oil_ Opportunities.pdf., Accra, Ghana, 4pp. Accessed: March 15, 2014.

Anon. (2010), "National Environmental Sanitation Strategy and Action Plan NESSAP: Materials in Transition MINT", Ghana, Ministry of Local Government and Rural Development, Accra, Ghana, 142pp.

Anon. (2012a), "The Composite Budget of the Sekondi-Takoradi Metropolitan Assembly for the 2012 Fiscal Year", www.ghanadistrics.com .Accessed: March 15, 2014.

Anon. (2012b), "Sekondi-Takoradi Citizen's Report Card 2012", CHF International and SekondiTakoradi Metropolitan Assembly (STMA), 55 pp.

Anon (2012c), "2010 Population and Housing Census", Ghana Statistical Service, Sakoa Press Limited, Accra, Ghana, 117 pp.

Oduro-Kwarteng, S., Anarfi, K. P. and Essandoh, H. M. K. (2016) 'Source separation and recycling potential of municipal solid waste in Ghana', Management of Environmental Quality: An International Journal, 27(2), pp. 210-226. doi: 10.1108/MEQ-03-2015-0038.

Bernache-Perez, G., Sanchez-Colon, S., Garmendia, A. M., Davila-Villareal, A. and Sanchez-Salazar, M. E. (2001), "Solid Waste Characterisation Study in the Guadalajara Metropolitan Zone, Mexico", Waste Management Research, Vol. 19, No. 5, pp. 413-424.

Bolaane, B. and Ali, M. (2004), "Sampling Household Waste at Source: Lessons Learnt in
Gaborone", Waste Management and Research Journal, pp. 142-148.

Bryant, I. M., Armah, F.A. and Pappoe, A. N. M. (2010), "Source Specific Quantification and Characterization of Solid Waste along a Sandy Beach in Cape Coast, Ghana", Theoretical and Empirical Researches in Urban Management, Vol. 8, No. 17, pp. 49-63.

Fakere, A. A., Fadairo, G. and Olusegun, O. (2012), "Domestic Waste Management and Urban Residential Environment: Focus on Akure, Nigeria", International Journal of Engineering and Technology, Vol. 2, No. 5, pp. 878-887.

Freduah, G. (2004), "Problems of Solid Waste Management in Nima, Accra", Unpublished BSc. Project Report, University of Ghana, Legon, pp 4.

Gomez, G., Meneses, M., Ballinas, L. and Castells, F. (2009), "Seasonal Characterization of Municipal Solid Waste (MSW) in the City of Chihuahua", International Journal of Waste Management, Vol. 29, No. 9, pp. 2018-2024.

Kazimbaya-Senkwe, B. and Mwale, A. H. (2001), "Solid Waste in Kitwe; Solid Waste Characterization Study for the City of Kitwe, Zambia: Phase 1", His Sinpa Papers Sinpa Number 28/2001 Zambia, SinpaProgramme, Institute for Housing and Urban Development Studies, Rotterdam, Netherlands in cooperation with Copperbelt University, Kitwe, Zambia, 57 pp.

Kui, L. (2007), "Study of Influence Factors in Municipal Solid Waste Management Decisionmaking", Unpublished MSc. Thesis Report, Industrial Ecology, Royal Institute of Technology, Stockholm, Sweden, pp. 1-43.

Lopez-Zavala, M. A. and Funamizu, N. (2005), "Effect of moisture content on the composting process in a biotoilet system", Compost science and utilization, Vol. 13, No. 3, pp. 208-216.

Mensah, A. and Larbi, E. (2005), "Solid Waste Disposal in Ghana" Well Fact Sheet-Regional Annex, http://www.lboro.ac.uk/well/resources/fact-sheets/fact-sheetshtm/RSA\%20Solid\%20waste-.htm.Accessed: Accessed: March 25, 2014.

Nabegu, A., B. (2010), "An analysis of Municipal Solid Waste in Kano Metropolis, Nigeria", Journal of Human Ecology, Vol. 31, No. 2, pp. 111-119.

Nordtest Environment 001 (1995), "Solid Waste, Municipal: Sampling and Characterisation". www.nordtest.org Accessed: March 25, 2014.

Ojeda-Benitez, S.G., Lozano-Olvera, R., Adalberto, M. and Armijo de Vega, C. (2008), "Mathematical Modeling to Predict Residential Solid Waste Generation", Journal of Waste Management, pp. 7-13.

Oumarou, M. B., Dauda, M., Abdulrahim, A.T. and Abubakar. A.B. (2012), "Characterization and 
Generation of Municipal Solid Waste in North Central Nigeria", International Journal of Modern Engineering Research (IJMER), Vol. 2, No. 5, pp. 3669-3672.

Oyelola, O. T. and Babatunde, A.I. (2008), "Characterization of Domestic and Market Solid Wastes at Sources in Lagos Metropolis, Lagos, Nigeria", African Journal of Environmental Science and Technology, Vol.3. No. 12, pp. 430437.

Planitz, E. and Kuzu, D, (2014), “Oil Production and its Impact on the Livelihood of Communities in Ghana”, Draft Report of Study - Preliminary Results, Ghana, 78 pp.

Puopiel, F. (2010), "Solid Waste Management in Ghana: The Case of Tamale Metropolitan Area", Unpublished MSc. Thesis Report, Kwame Nkrumah University of Science and Technology, Kumasi, Ghana, 93 pp.

Qdais, A., Hamoda, M. F. and Newham, J. (1997), "Analysis of Residential Solid Waste at Generation Sites", Waste Management and Research Journal, Vol. 15, pp. 395-406.

Quayson, F. A. (2012), "Oil City? The Role of Sekondi-Takoradi in Ghana's Emerging Oil Industry", Unpublished MPhil. Thesis Report, Norwegian University of Science and Technology, Trondheim, Norway, 132 pp.

Walling, E., Walston, A., Warren, E., Warshay, B. and Wilhelm, E. (2004), Municipal Solid Waste Management in Developing Countries: Nigeria, a Case Study, Nigeria, 16pp.

\section{Authors}

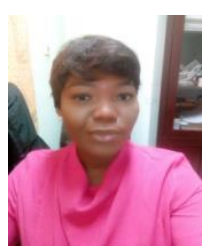

V. I. Seshie is Research Fellow of Environmental and Safety Engineering at the University of Mines and Technology, Tarkwa, Ghana. She holds a BSc in Laboratory Technology from the University of Cape Coast, Cape Coast, Ghana, MSc in Environmental Science from the Kwame Nkrumah University of Science and Technology, Kumasi, Ghana and a $\mathrm{PhD}$ candidate with the University of Mines and Technology, Ghana. Her area of research interest includes, Environmental Assessment, Municipal Solid Waste Management, Waste Characterization and Occupational Health and Safety.

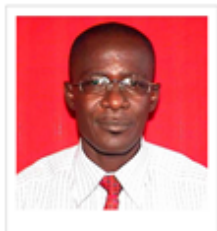

K. Obiri-Danso is a Professor of Microbiology/Environmental Health at the Department of Theoretical and Applied Biology of the College of Science, Kwame Nkrumah University of Science and Technology (KNUST), Kumasi, Ghana. He holds a BSc in Biological Science and an MPhil in Food Microbiology from the KNUST, and a PhD. in Environmental Microbiology from Lancaster University, UK. His area of research interest includes Monitoring and Evaluation of Resistance in Humans, Food Animals, Water, And Vegetables

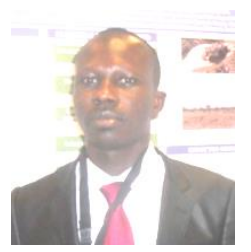

K. Miezah is currently a Lecturer at the Environmental Science Department, College of Science, Kwame Nkrumah University of Science and Technology, (KNUST), Kumasi. He holds BSc Chemistry, MPhil Environmental Science and $\mathrm{PhD}$ Environmental Science with DTU, Denmark and KNUST. He is a member of the International Solid Waste Association (ISWA) and Solid Waste Association of North America (SWANA). He has deep experience in managing waste of various types and his research interest in waste characterization, biofuel production, waste collection and transportation concepts, landfill management and environmental sanitation. 